\title{
Aplikasi Geolistrik Resistivitas Konfigurasi Wenner-Schlumberger untuk Pemetaan Sebaran Leachate di Sekitar TPA Putri Cempo Surakarta
}

\author{
Chiranjeevi Nugroho, ${ }^{*}$ Darsono, dan Ari Handono Ramelan \\ Program Studi Fisika, Fakultas Matematika dan Ilmu Pengetahuan Alam, \\ Universitas Sebelas Maret (UNS), Jl. Ir. Sutami No. 36 A Kentingan, Surakarta 57126
}

\begin{abstract}
Intisari
Pemetaan sebaran lindi menggunakan metode geolistrik resistivitas telah dilakukan di Desa Plesungan, Gondang Rejo, Kabupaten Karanganyar. Proses akuisisi data menggunakan konfigurasi Wenner-Schlumberger dengan spasi elektroda terkecil berjarak 15 meter. Alat yang digunakan resistivitymeter OYO McOHM-EL untuk menginjeksikan arus kedalam bumi dan mengukur beda potensial yang terjadi. Proses inversi data menggunakan software Res2dInv untuk pemodelan secara 2 dimensi dan software Rockworks 16 untuk pemodelan secara 3 dimensi. Lokasi penelitian mempunyai geologi alluvium tua dengan karakteristik konglomerat, batupasir, lanau dan lempung. Penyebaran lindi diperkirakan dengan nilai resistivitas $<5.55 \Omega . m$ dengan arah menjauhi lokasi TPA dimana batuan penyusun lokasi penelitian mayoritasnya adalah lempung.
\end{abstract}

\begin{abstract}
Mapping leachates distribution using geoelectrical resistivity has been done at Plesungan village, Gondang Rejo, Karanganyar regency. Acquisition using Wenner-Schlumberger configuration with space of the smallest electrode is 15 meters away. This research uses resistivitymeter OYO McOHM-EL for current injection and measure the potential difference. Inversion process uses Res2dInv software for 2 dimensions model and RockWorks 16 software for 3 dimensions model. The location of the research has geology old alluvium with characteristics conglomerate, sandstone, silt and clay. Leachate mapping estimates resistivity value of $<5.55 \Omega . \mathrm{m}$ with the direction away from the final disposal site where the main constituent of reseach sites is clay.
\end{abstract}

KATA KUNCI: Mapping, Geoelectrical Resistivity, Leachate http://dx.doi.org/10.12962/j24604682.v14i1.2864

\section{PENDAHULUAN}

Sampah adalah suatu bahan terbuang dan tidak memiliki nilai ekonomis yang terbentuk dari aktifitas manusia. Tingginya tingkat kebutuhan masyarakat membuat debit sampah yang terjadi bertambah serta hal terkait sampah tidak dapat diabaikan karena berkaitan dengan pola hidup dan kesehatan [1]. Sampah yang dihasilkan dari semua tempat akan menuju ke tempat pembuangan akhir(TPA). Tipe TPA diantaranya Open Dumping, Control Landfill dan Sanitary Landfill dimana Open Dumping adalah tipe yang dapat menyebabkan kerusakan terbanyak karena bersifat terbuka sehingga sampah yang tertumpuk akan terkena panas maupun hujan sehingga menghasilkan leachate (lindi) dengan membawa senyawa kimia yang dapat mencemari air tanah disekitar daerah tersebut, menimbulkan bau tidak sedap serta mendatangkan lalat yang sangat banyak [2]. Lindi terbentuk karena sampah pada tipe TPA seperti tipe Open Dumping yang mudah terkena panas dan terkena hujan, lalu air hujan tersebut terkena sampah dan senyawa sampahnya terurai secara fisika, kimia maupun biol-

*E-MAIL: chiran_m0213019estudent.uns.ac.id ogis. Air dari sampah tersebut disebut denganlindi dan akan meresap ke tanah [3] dengan membawa senyawa-senyawa kimia yaitu $\mathrm{NH}_{3}, \mathrm{Ca}, \mathrm{Mg}, \mathrm{Na}, \mathrm{Fe}, \mathrm{Cl}, \mathrm{K}, \mathrm{SO}_{4}$ [4] dan logam berat diantaranya $\mathrm{Hg}, \mathrm{Cd}, \mathrm{Cu}, \mathrm{Ag}, \mathrm{Ni}, \mathrm{Pb}, \mathrm{As}, \mathrm{Cr}, \mathrm{Sn}, \mathrm{Zn}$ dan Mn [5]. Pencemaran oleh lindi tersebut dapat dilihat menggunakan salah satu dari ilmu geofisika yaitu geolistrik resistivitas yang mempelajari tentang keresistivitasan.

Metode geolistrik dilakukan dengan memasukkan arus listrik ke bawah permukaan tanah dengan satu pasang elektroda dan menilai tegangan dari satu pasang elektroda lainnya sehingga dapat terlihat besarnya nilai resistivitas [6] dan resistivitas semunya [7]. Geolistrik resistivitas juga sering digunakan untuk memprediksi resiko limbah terhadap air tanah di daerah yang sedang diukur [8]. Penelitian dengan metode ini telah dilakukan oleh Audebert et al. (2016) [9], Audebert et al. (2016) [10], Bichet et al. (2016) [11], Degueurce et al. (2016) [12] yang menggunakan geolistrik resistivitas konfigurasi Wenner-Schlumberger untuk memonitor sebaran lindi. Electrical Resistivity Tomography (ERT) mengukur berdasarkan nilai resistivitas dari material bawah tanah. Metode ini memunculkan hasil seperti kedalaman, ketebalan suatu material, penyebaran lindi serta dapat melihat retakan dan patahan [13]. Dengan adanya lindi di dalam tanah menyebabkan nilai resistivitas menjadi rendah sehingga terdapat 
LINE 1

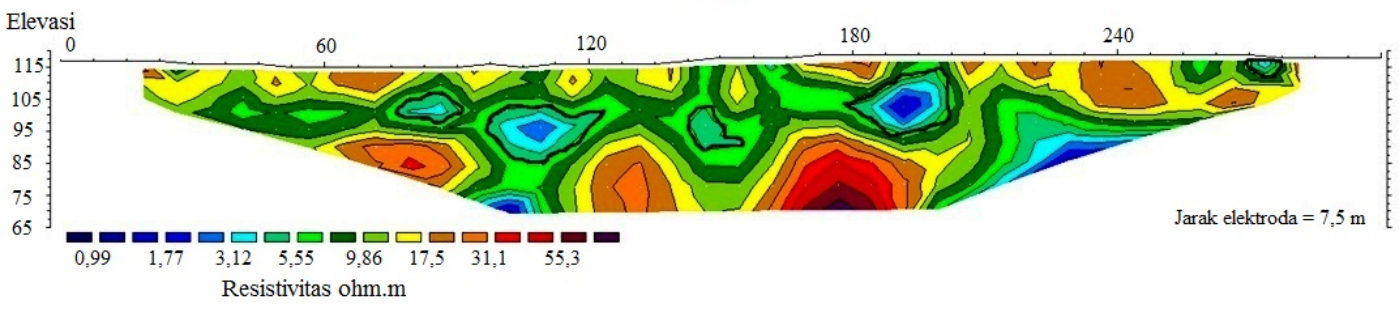

Gambar 1: Hasil inversi 2 dimensi lintasan 1.

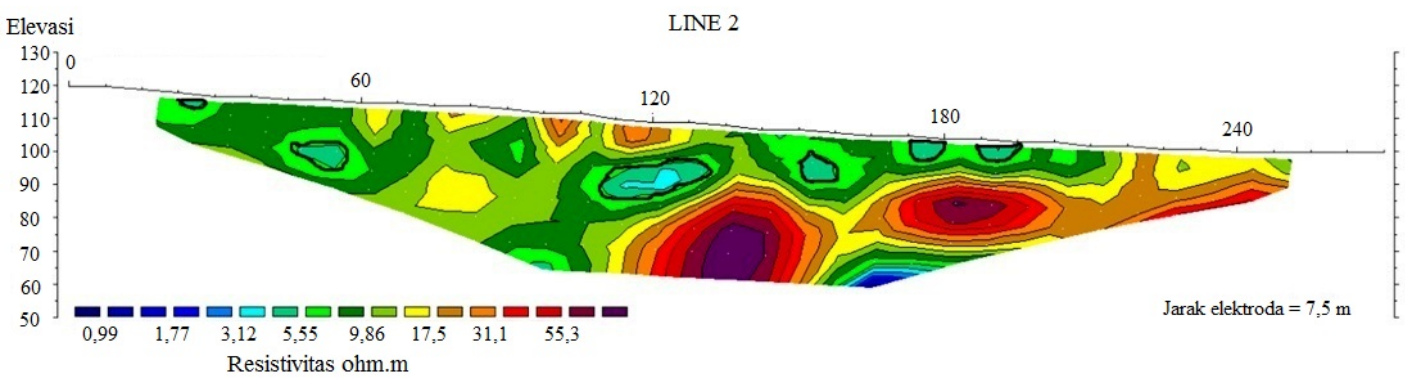

Gambar 2: Hasil inversi 2 dimensi lintasan 2.

kontras resistivitas dengan sekitarnya. Metode geolistrik dapat digunakan karena adanya kontras resistivitas pada daerah tersebut. Pemetaan lindi sangat penting dilakukan karena berhubungan dengan pencemaran air tanah pada daerah tersebut karena air adalah sumber manusia untuk memenuhi kebutuhan hidup sehari-hari [11].

\section{METODE PENELITIAN}

\section{Alat}

Alat yang digunakan dalam penelitian ini antara lain Resistivitymeter OYO McOHM-EL untuk meninjeksikan arus dan membaca beda potensial, elektroda untuk meninjeksikan arus ke bumi dan menangkap beda potensial, kabel untuk menghubungkan elektroda dengan resistivitymeter, meteran untuk mengukur panjang lintasan, Accu $12 \mathrm{~V}$ sebagai sumber daya resistivitymeter, GPS untuk menunjukkan koordinat titik pengambilan data dan palu untuk membantu menancapkan elektroda kedalam tanah.

\section{Pengambilan data}

Penelitian ini berlokasikan di desa Plesungan, Gondang Rejo, kabupaten Karanganyar dengan titik lokasi 0484265-9166570 untuk lintasan pertama, 0484346-9166637 untuk lintasan kedua dan 0484194-9166751 untuk lintasan ketiga. Penelitian ini menggunakan konfigurasi Wenner-Schlumberger dengan spasi elektroda terdekat 15 meter, faktor pengali 7, panjang bentangan adalah 300 meter, 270 meter dan 285 meter untuk lintasan pertama, lintasan kedua dan lintasan ketiga secara berurutan.

\section{Pengolahan data}

Pengolahan data untuk menghasilkan pemetaan secara 2 dimensi menggunakan software Res $2 d I n v$ dengan memasukkan posisi elektroda pertama, spasi elektroda terkecil, faktor pengali dan nilai resistivitas semu. Pengolahan data untuk menghasilkan pemetaan secara 3 dimensi menggunakan software RockWorks dengan memasukkan nama file per-datum points, posisi GPS serta ketinggian setiap titik, kedalaman total, kedalaman dan nilai resistivitas yang berasal dari output Res2dInv.

\section{HASIL DAN PEMBAHASAN}

Hasil penelitian ditunjukan dengan kontras warna pada hasil gambar. Nilai resistivitas dalam satuan $\Omega$.m pada hasil dengan rentang nilai tertentu yang ditandai dengan warna tertentu menunjukkan distribusi yang homogen.

Profil rentang resistivitas pada lintasan 1 , lintasan 2 dan lintasan 3 disamakan, sehingga interpretasi pada lintasan 1, lintasan 2 dan lintasan 3 akan sama pada tiap rentang nilai resistivitas. Pada penelitian lindi diperkirakan berada pada rentang resistivitas $<5,55$ S.m, lempung hingga lempung pasiran pada rentang 5,56-24,3 $\Omega$.m dan pasir lempungan hingga pasir pada rentang 24.4-113.52 $\Omega . m$. Batuan penyusun dari lokasi penelitian adalah lempung, lanau dan pasir. Terlihat pada Gambar 1, 2 dan 3 didominasi oleh warna hijau hingga warna ungu.

Lindi pada Gambar 1 berada pada bentangan 82,5 meter, 112,5 meter, 142,5 meter dan 187,5 meter dengan kedalaman 10-15 meter dari permukaan. Lindi dengan konsentrasi yang besar terlihat pada bentangan 187,5, ditandakan dengan ni- 


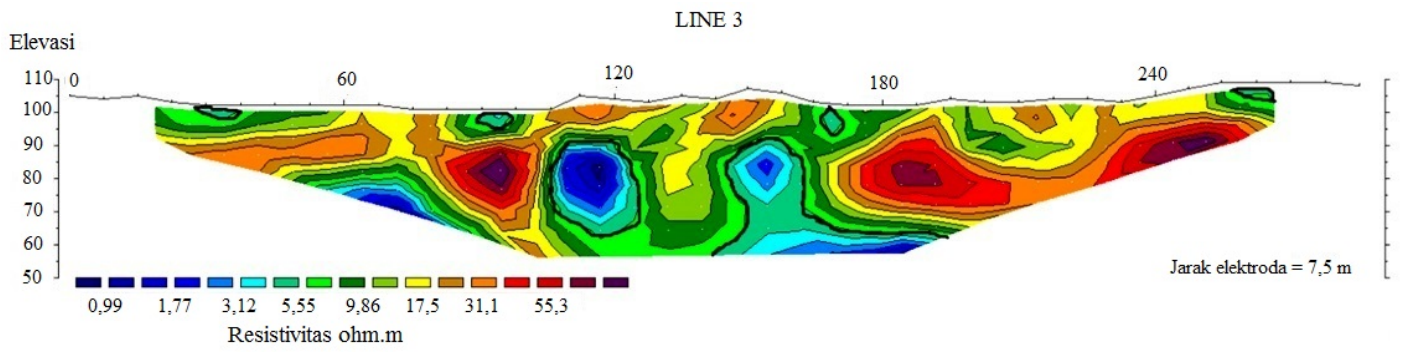

Gambar 3: Hasil inversi 2 dimensi lintasan 3.

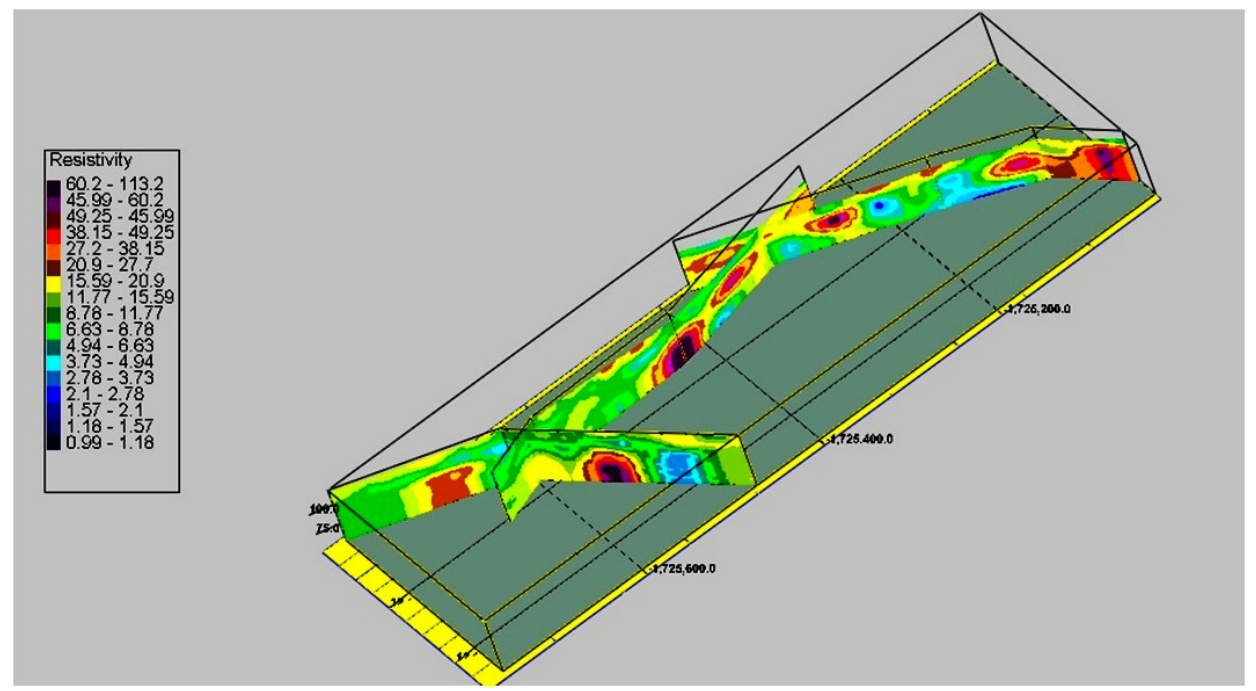

Gambar 4: Diagram Fence untuk melihat korelasi lintasan 1, lintasan 2 dan lintasan 3.

lai resistivitas yang lebih kecil dibandingkan pada bentangan yang lainnya.

Lindi pada Gambar 2 tidak sebanyak pada lintasan 1 dan lintasan 3 dikarenakan posisinya tidak sejajar dengan posisi lindi. Lindi pada lintasan 2 diperkirakan terbentuk pada bentangan 22,5 meter, 52,5 meter, 120 meter, 150 meter dan 180 meter. Lindi pada bentangan 22,5 meter, 52,5 meter dan 180 meter diperkirakan berasal dari atas permukaan tanah karena pada lokasi penelitian terdapat lindi pada posisi tersebut.

Lindi pada Gambar 3 dengan bentangan 262,5 meter diperkirakan lindi permukaan karena posisi tersebut melewati tempat sampah warga yang terdapat lindi. Pada bentangan 30 meter, 90 meter dan 172,5 meter lindi merupakan sebaran dari lindi yang lebih besar, yaitu pada bentangan 112,5 meter dan 150 meter. Lindi pada lintasan 3 ini terlihat mempunyai konsentrasi lindi yang lebih besar dibandingkan pada lintasan 1 dan lintasan 2 karena lintasan 3 lokasi lebih dekat dengan sungai lindi TPA Putri Cempo.

Profil lintasan 1, lintasan 2 dan lintasan 3 digabungkan dengan menggunakan software Rockworks dan menghasilkan diagram Fence yang ditunjukkan pada Gambar 4. Fungsi dari diagram Fence untuk memperlihatkan hubungan tiap-tiap lintasan hasil 2 dimensi sehingga dapat diperkirakan hubungan yang terjadi dari hasil inversi 2 dimensinya.

Pada Gambar 4 terlihat korelasi antar tiap-tiap lintasan. Setelah melihat korelasi antar tiap-tiap lintasan, dibuat model 3 dimensi dari hasil penelitian. Hasil 3 dimensi tersebut diperkirakan bentuk real dari lokasi penelitian.

Hasil 3 dimensi dari Gambar 5 dapat difilter agar terlihat rentang resistivitas yang diinginkan. Pemfilteran dapat dilakukan untuk memperlihatkan rentang resistivitas yang tinggi ataupun menunjukkan nilai resistivitas yang rendah. Gambar 6 memperlihatkan penyebaran lindi dalam bentuk 3 dimensi. Pemfilteran dilakukan untuk mengambil nilai resistivitas rendah, yaitu $<5.55 \Omega . m$ yang diperkirakan sebagai lindi pada penelitian ini.

\section{SIMPULAN}

Berdasarkan penelitian ini, penyebaran lindi dari TPA Putri Cempo sudah mencapai lintasan 1 dimana lintasan 1 mempunyai lokasi yang cukup jauh dari sungai lindi dengan perkiraan lindi $<5.55 \Omega$.m dengan batuan penyusun dari lokasi penelitian adalah lempung, lanau dan pasir. 


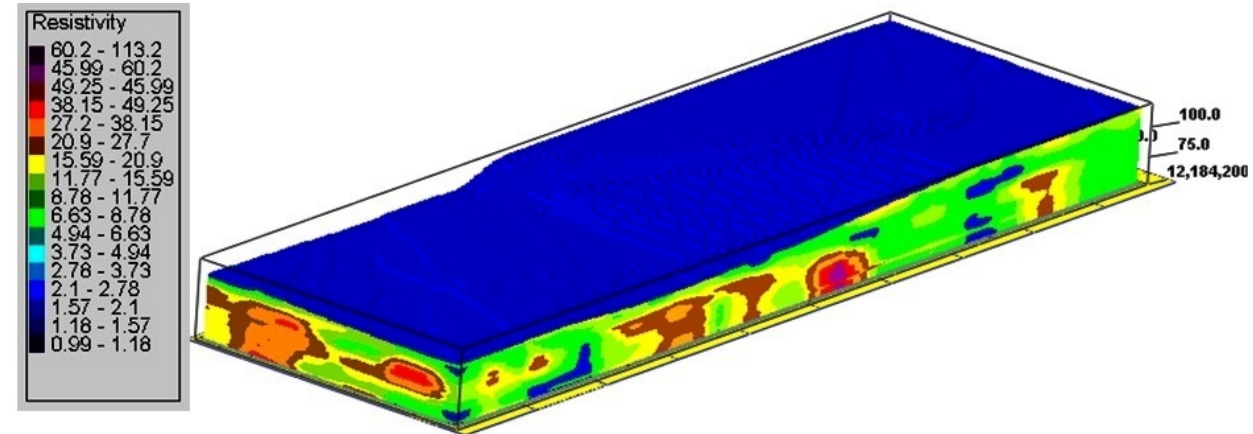

Gambar 5: Bentuk 3 dimensi dari lokasi penelitian berdasarkan hasil 2 dimensi.

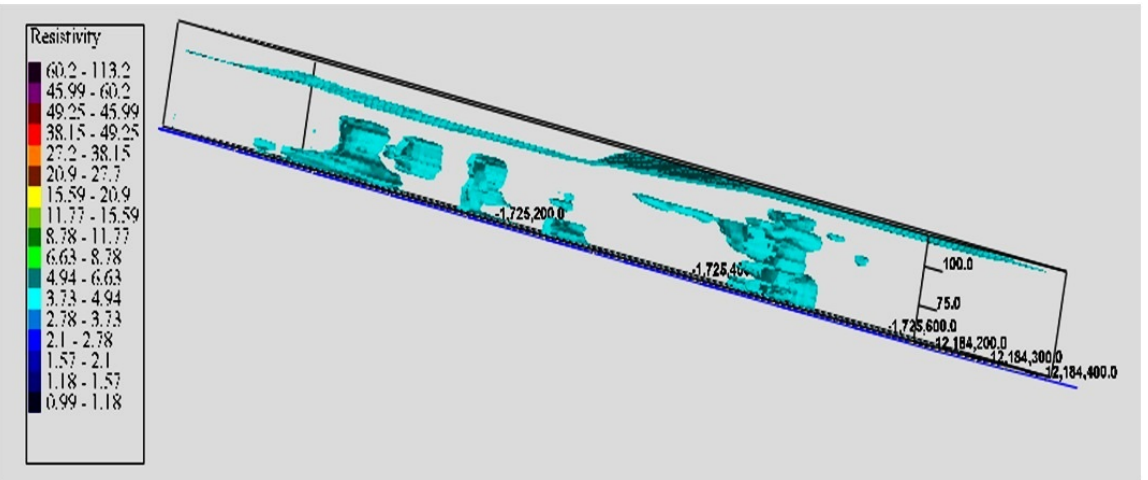

Gambar 6: Perkiraan penyebaran lindi dalam bentuk 3 dimensi.

[1] M. Rizal, ”Analisis Pengelolaan Persampahan Perkotaan”, Jurnal SMARTek, vol. 9, No. 2, pp. 155-172, 2011.

[2] E. Damanhuri, dan T. Padmi, Diktat Kuliah TL:3104 "Pengolahan Sampah”, Program Studi Teknik Lingkungan ITB, Bandung, 2010.

[3] M. Ali, "Monograf Rembesan Air Lindi (Leachate) Dampak pada Tanaman Pangan dan Kesehatan", UPN Press, Surabaya, 2011.

[4] O.S. Aboyeji, and S.F. Eigbokhan, "Evaluations of groundwater contamination by leachate around Olusosun open dumpsite in Lagos metropolis, southwest Nigeria. Journal of Enviromental Management", Journal of Enviromental Management, vol. 183, pp. 333-341, 2016.

[5] L. Susanawati, B. Suharto, Kustamar, "Penurunan Kandungan Logam Berat Pada Air Lindi dengan Media Zeolit Menggunakan Metode Batch dan Metode Kontinyu", AGROINTEK, vol. 5, No. 2, pp. 141-147, 2011.

[6] J.M. Reynolds, (2011). "An Introduction to Applied and Environmental Geophysics", Second Edition, United Kingdom: John Wiley \& Sons Ltd. Publication, 2011.

[7] A.S. Wijaya, "Aplikasi Metode Geolistrik Resistivitas Konfigurasi Wenner untuk Menentukan Struktur Tanah di Halaman Belakang SCC ITS Surabaya”, Jurnal Fisika Indonesia, vol. 19, no. 55, pp. 1-5, 2015.

[8] A. Younis, M. Soliman, S. Moussa, U. Massoud, S. ElNabi, M. Attia, "Integrated geophysical application to investigate groundwater potentiality of the shallow Nubian aquifer at northen
Kharga”, Western Desert, Journal of Astronomy and Geophysics, vol. 5, pp. 186-197, 2016.

[9] M. Audubert, R. Clment, S. Moreau, C. Duquennoi, S. Loisel, N. Touze-Foltz, "Understanding leachate flow in municipal solid waste landfills by combinating time-lapse ERT and subsurface flow modelling Part I: Analysis of infiltration shape on two different waste deposit cells", Waste Management, vol. 55, pp. 165175,2016

[10] M. Audubert, L. Oxarango, C. Duquennoi, N. Touze-Foltz, N. Forquet, R. Clment, "Understanding leachate flow in municipal solid waste landfills by combinating time-lapse ERT and subsurface flow modelling Part II: Constraint methodology of hydrodynamic models", Waste Management, vol. 55, pp. 176-190, 2016.

[11] V. Bichet, E. Grisey, L. Aleya, "Spatial characterization of leachate plume using electrical resistivity tomography in a landfill composed of old and new cells (Bellfort, France)", Engineering Geology, vol. 211, pp. 61-73, 2016.

[12] A. Degueurce, R. Clment, S. Moreau, P. Peu, "On the value of electrical resistivity tomography for monitoring leachate injection in solid state anaerobic digestion plants at farm scale", Waste Management, vol. 56, pp. 125-136, 2016.

[13] D.A. Enggarwati, A. Susilo, D.D. Wardhana, "Pendugaan Akuifer serta Pola Alirannya dengan Metode Geolistrik Daerah Pondok Pesantren Gontor 11 Solok Sumatera Barat", Physics Student Journal, vol. 2, no. 1, pp. 549-553, 2014. 